\title{
Enhancing Export Diversification in Resource-Rich Economies - Policies and Evidence from Kazakhstan
}

\author{
P. Zhelev ${ }^{1,2^{*}}$ \\ * Corresponding author: pzhelev@unwe.bg. \\ ${ }^{1}$ University of National and World Economy, Sofia, Bulgaria \\ ${ }^{2}$ Korkyt Ata Kyzylorda State University, Kyzylorda, Kazakhstan
}

\begin{abstract}
Kazakhstan has managed to benefit from its considerable endowments of natural resources during the commodity price boom in the 2000s. However, the global crisis of 2008-09 has demonstrated that relying on a single sector prone to high price volatility cannot be a viable strategy for development. The government of Kazakhstan well realizes that and for already 2 decades has been pursuing various industrial policy initiatives to build a more diversified and competitive economy. The paper aims to examine how successful were those policies by applying various indicators of export diversification. The results show that progress has been very limited as the country's export basket is highly concentrated and still dominated by oil. This suggests that Kazakhstan should ensure better implementation, coordination, monitoring and evaluation of its diversification initiatives.
\end{abstract}

Keywords: export, diversification, policy, natural resources.

\section{Introduction}

Kazakhstan, the biggest economy in Central Asia, is a resource-rich country endowed with considerable amounts of natural resources including coal, oil, gas, uranium, copper, iron, zinc. At the end of 2018 Kazakhstan possessed 2.4\% (10th position in the world) of the total world proved coal resources, $0.5 \%$ (24th position) of natural gas and $1.7 \%$ (12th position) of oil [1]. Capitalizing on its extensive natural resources and favourable world conjuncture with exceptionally high commodity prices (driven mainly by the booming demand for natural resources of China) it has registered impressive growth rates since the early 2000s. That made possible building infrastructure, fighting poverty, increasing GDP per capita and already in 2006 entering the upper-middle-income group of countries.

However, this remarkable economic performance and the related increase in living standards have been largely due to the country's extractive industries and especially oil, accounting for more than half of exports and a large percentage of total government revenue [2]. This concentration on a single sector that moreover is notorious for being characterized by high price volatility makes Kazakhstan extremely vulnerable to external shocks. The Great Recession and the end of the commodity price boom with the subsequent slump in the economic growth in resource-rich Central Asian countries have demonstrated that such a growth model based on commodities export cannot be sustained in the long-term.

While Kazakhstan's proven oil reserves are estimated at 30 billion barrels and based on current production levels (about 1.67 million barrels per day as of 2018 according to BP data [1]) it will take more than 42 years to full depletion of its proven oil resources, the country will be affected much sooner by the forthcoming developments in the global market for fossil fuels. In a recent study the EBRD (2018) expects significant changes in fossil fuel industries that due to technological changes and fulfilment of climate change commitments embodied in the UN's SDGs and the Paris Agreement by major countries will lead to a transition to a green global economy which will keep prices of oil subdued. That will pose significant economic risks to Kazakhstan and requires resolute policy measures to encourage growth of the non-oil sectors and promote structural transformation of the economy [3]. In various country reports the OECD has also identified economic diversification as one of the major challenges for Kazakhstan [4].

The Kazakh government well realizes that it is imperative for the national interest to develop a more diversified and competitive economy and in line with that it has enacted various industrial policy initiatives since the end of the 1990s.

In this context, the main objective of the paper is to examine how successful were the industrial policy initiatives pursued by Kazakhstan in the last decade by analysing the export diversification of its economy.

\section{Methods}

Various studies discussed economic diversification in Kazakhstan. Based on the Herfindahl-Hirschman Index for the period 2005-2015, Bayramov and Orujova (2017) find out that the exports of Kazakhstan were highly concentrated that raises concerns regarding the sustainability of long-term economic growth in the economy [5].

A report of the Asian Bank for Development (2018) used the number of products exported with revealed comparative advantage (RCA) to measure the diversification of the Kazakh economy. It covered data for the period 1995-2015 and found out that overall diversification deteriorated, as the total number of products with comparative advantage fell from 82 in 1995 to 45 to 2010, and picked up only slightly to 60 in 2015 [2]. Discussing Kazakhstan's 
diversification initiatives Howie (2018) also contends that they have not resulted in increasing the range of the country's exports [6].

Since previous studies cover data up to 2015 it is instructive to see whether the continuous implementation and updating of the economic diversification policy of Kazakhstan has managed to produce better results in the following years by using more recent data.

Export diversification could be measured by various trade indicators. Since any single indicator has its limitations we are going to apply a broader set of indicators:

- share of manufactured goods vs. primary commodities in total merchandise exports;

- share of the top three goods exports in total exports of the country;

- number of exported products.

In addition, we are going to use several more complex trade indicators computed by the UNCTAD, presented in table 1 .

Table 1. Selected trade indicators used for measuring export diversification.

\begin{tabular}{|c|c|c|}
\hline Trade indicator & Formula & Meaning \\
\hline $\begin{array}{l}\text { Concentration } \\
\text { index } \\
\text { (Herfindahl- } \\
\text { Hirschmann } \\
\text { Index - HHI) }\end{array}$ & $\begin{array}{c}\qquad H_{j}=\frac{\sqrt{\sum_{i=1}^{n}\left(\frac{x_{i j}}{X_{j}}\right)^{2}-\sqrt{1 / n}}}{1-\sqrt{1 / n}} \\
\text { where xij }=\text { value of export for country } \mathrm{j} \text { and product } \mathrm{i} \\
\mathrm{n}=\text { number of products (SITC Revision 3 at 3-digit } \\
\text { group level) }\end{array}$ & $\begin{array}{l}\text { HHI index value closer to } 1 \\
\text { indicates a country's exports are } \\
\text { highly concentrated on a few } \\
\text { products. On the contrary, values } \\
\text { closer to } 0 \text { reflect exports are more } \\
\text { homogeneously distributed among a } \\
\text { series of products. }\end{array}$ \\
\hline $\begin{array}{l}\text { Diversification } \\
\text { index }\end{array}$ & $\begin{array}{c}S_{j}=\frac{\sum_{i}\left|h_{i j}-h_{i}\right|}{2} \\
\text { where: hij }=\text { share of product } \mathrm{i} \text { in total exports of } \\
\text { country } \mathrm{j} \\
\mathrm{hi}=\text { share of product } \mathrm{i} \text { in total world exports }\end{array}$ & $\begin{array}{l}\text { The index is calculated by } \\
\text { measuring the absolute deviation of } \\
\text { the export structure of a country } \\
\text { from the world structure. It takes } \\
\text { value between o and } 1 \text { and a value } \\
\text { closer to } 1 \text { indicates greater } \\
\text { divergence from the world pattern. }\end{array}$ \\
\hline RCA index & $\begin{array}{l}\qquad R C A_{i j}=\frac{x_{i j}}{x_{i t}} \div \frac{x_{w j}}{x_{w t}} \\
\text { where Xij and Xwj, are values of country i's and world } \\
\text { exports of product j, respectively; } \\
\text { Xit and Xwt are values of country i's total exports and } \\
\text { world total exports, respectively }\end{array}$ & $\begin{array}{l}\text { RCA index measures the existence } \\
\text { of comparative advantage by } \\
\text { comparing the country of interests' } \\
\text { export profile with the world } \\
\text { average. Country i has a CA in a } \\
\text { product } j \text { when its ratio of exports of } \\
\text { product } j \text { to its total good exports } \\
\text { exceeds the same ratio for the world } \\
\text { as a whole, i.e when } \mathrm{RCA}>1 \text {. }\end{array}$ \\
\hline
\end{tabular}

Source: compiled by the author based on UNCTAD [7].

\section{Policies for export diversification in Kazakhstan}

Kazakhstan has been trying to diversify its economy since 1997 when it introduced for the first time a long-term development strategy Kazakhstan-2030 which laid the ground for further strategic documents and policies for economic diversification. Accordingly, a Strategy for Industrial and Innovative Development 2003-2015 (SIID 2003-2015) was adopted which aimed at supporting modernization and diversification of the Kazakh economy. While over the period the dependence on extractive industries continued, one of the major outcomes of the programme was the establishment of technology parks, industrial zones and institutes of development [6].

The institutions that were established to carry out the diversification strategy included: the Development Bank of Kazakhstan, the Investment Fund of Kazakhstan, the National Innovation Fund, and the Export Insurance Corporation. With a view to improve efficiency and management in 2006 Kazyna Sustainable Development Fund was created and it absorbed all of the development agencies. In 2008 it merged with the Samruk State Holding Co. to form Sovereign Wealth Fund Samruk-Kazyna JSC where the sole shareholder is the government of Kazakhstan. Samruk-Kazyna JSC Group includes enterprises operating in several industries - oil, transport and logistics, chemical and nuclear, mining and smelting, energy, mechanical engineering and real estate and as of 2018 the Fund and its portfolio companies share in the economy amounted to KZT 4 trillion [8].

After the Global Financial Crisis, the SIID 2003-2015 was revised and the National Program for Forced Industrial and Innovative Development (2010-2014) (NPFIID) was launched. Its objective is to "guarantee stable and wellbalanced economic growth by means of diversification and improvement of its competitive ability." To achieve concentration of resources of government and businesses priority sectors for development were identified: traditional (oil and gas sector, ore mining and smelting complex, atomic and chemical industry); based on national demand (machinery, building industry, pharmaceutics); export-oriented sectors (agro-industrial complex, light industry, tourism); sectors "of economy of the future" (ICTs, biotechnologies, alternative energetics, space activities) [9]. 
In 2015 the Ministry of Economy evaluated the NPFIID and found out that out of the 191 evaluation criteria 147 were achieved (44 not) and despite some positive impact on the economy the major goal of diversification was not attained. The factors behind that included: large coverage of economic sectors, projects, and indicators considered by the programme; deterioration of external economic factors; and underfunding of the NPFIID. Furthermore, there was little involvement of the private sector and the regions in the implementation of the programme, inefficient coordination between state bodies, and a poor methodology for monitoring and evaluation [2].

Based on the experience with NPFIID and as its logical continuation and following the long-term priorities of the Strategy "Kazakhstan-2050" for the implementation of key direction "Accelerating economic diversification", the State program on industrial-innovative development of Kazakhstan for 2015-2019 (SPIID) was designed [10]. The SPIID has a bigger budget (KZT 1.7 billion), less priorities (ferrous and nonferrous metallurgy, oil processing, petro-chemistry and agro-chemistry, food production, car manufacturing, and electro-technical machine building) and improved coordination, monitoring and control. Furthermore, the program aims at fostering the development of regional industrial clusters, improvement of the business climate, stimulating entrepreneurship and SMEs and attracting foreign direct investment by providing fiscal and non-fiscal stimuli. A special focus is put on internationalization and a major criterion for providing state support is export-orientation of the project.

In the next section we will explore the results achieved by the industrial policy in Kazakhstan in terms of diversifying the economy away from extractive industries.

\section{Export diversification of Kazakhstan during the last decade}

One of the major goals of diversification is to generate exports outside the resource sector in order to lower export volatility and vulnerability to external shocks. Looking at the data for the structure of exports of Kazakhstan on Fig.1 we see that primary commodities continue to dominate and even increase their significance in the country's export basket. In 2008 they accounted for $85.4 \%$ of the exports while in 2018 their share was already $87.6 \%$. At the same time manufactured goods have decreased their share from $13.8 \%$ to $12.4 \%$.

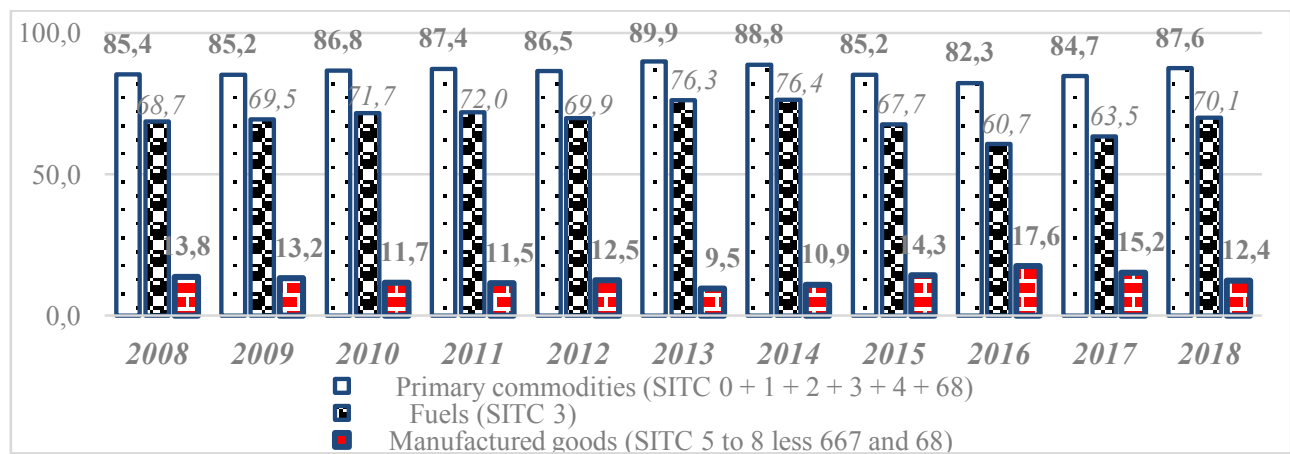

Fig. 1. Primary commodities and manufactured goods exports of Kazakhstan in 2008-2018 (\% of total merchandise exports), Source: compiled by the author based on UNCTAD data.

Another perspective is given by looking at more detailed export data. It shows that the share of the top 3 products in Kazakhstan's exports has been hovering between $67 \%$ and $71 \%$ and in 2018 it stood at $69.3 \%$. Moreover, just one product (defined at the 6-digit HS code) - crude petroleum oil - accounted for the staggering $62 \%$ of all merchandise exports in 2018. This represents extremely high concentration and dependence on just a single product. The other two top export products in the Kazakh export list - refined copper (3.7\%) and natural gas (3.6\%) are also highly resourceintensive and expand the resource dependence of the country (Fig. 2).

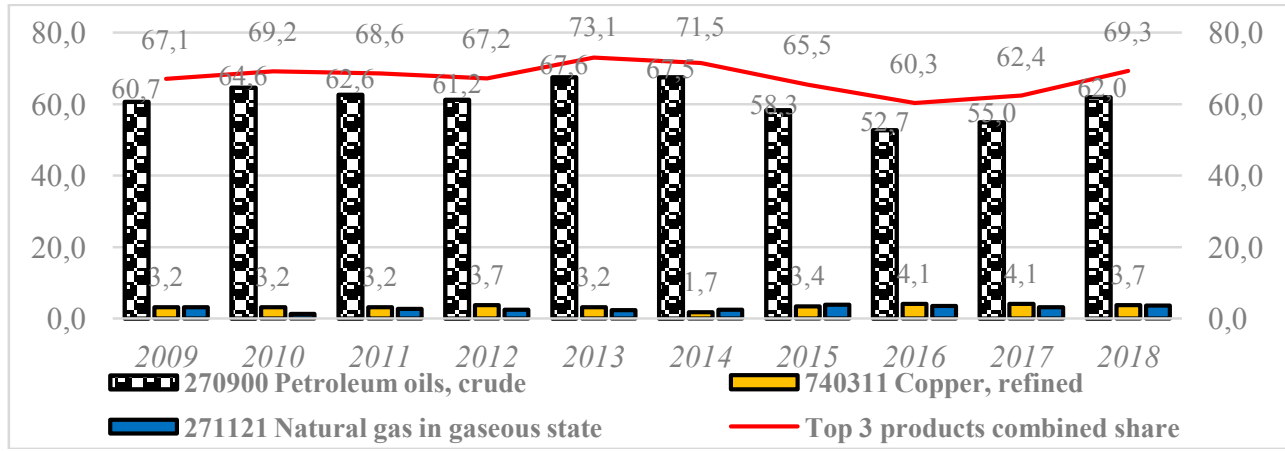

Fig. 2. Share of top three 6-digit HS products in total merchandise exports of Kazakhstan in 2009-2018 (\%), Source: compiled by the author based on International Trade Centre data [11]. 
The high export concentration is confirmed by both the concentration and diversification indices. During the last 10 years they have increased their values in the case of Kazakhstan which means that concentration of the country's exports and its divergence from the world export pattern have become more pronounced (Table 2). This is in contrast to the trend in 3 groups of countries to which Kazakhstan belongs (upper-middle-income economies, exporters of petroleum and emerging markets) which for the period 2008-2018 have managed to improve their performance in terms of export diversification.

Table 2. Selected indicators for export diversification of Kazakhstan and selected group of countries.

\begin{tabular}{|l|l|l|l|l|l|l|}
\hline & \multicolumn{2}{|l|}{$\begin{array}{l}\text { Number of } \\
\text { exported products }\end{array}$} & $\begin{array}{l}\text { Concentration } \\
\text { index (HHI index) }\end{array}$ & \multicolumn{2}{l|}{ Diversification index } \\
\cline { 2 - 8 } & $\mathbf{2 0 0 8}$ & $\mathbf{2 0 1 8}$ & $\mathbf{2 0 0 8}$ & $\mathbf{2 0 1 8}$ & $\mathbf{2 0 0 8}$ & $\mathbf{2 0 1 8}$ \\
\hline Kazakhstan (KZ) & 210 & 235 & 0.59 & 0.60 & 0.74 & 0.79 \\
\hline Upper-middle-income economies & 260 & 260 & 0.15 & 0.09 & 0.23 & 0.20 \\
\hline Selected exporters of petroleum & 258 & 260 & 0.60 & 0.46 & 0.66 & 0.64 \\
\hline Emerging markets: Europe and KZ & 258 & 257 & 0.17 & 0.13 & 0.31 & 0.29 \\
\hline
\end{tabular}

Source: compiled by the author based on UNCTAD data.

On the positive side, Kazakhstan has managed to increase the number of exported products - from 210 in 2008 to 235 in 2018 (Table 3). However, the comparison with the countries from the same income group and region and those specialized in exports of petroleum again shows significant lagging behind.

Table 3. Product groups with gained and lost comparative advantage of Kazakhstan over 2008-2018.

\begin{tabular}{|l|l|l|l|l|l|}
\hline \multicolumn{2}{|l|}{ Product groups with gained CA } & \multicolumn{2}{l|}{ Product groups with lost CA } \\
\hline Product (3-digit SITC) & $\begin{array}{l}\text { RCAi in } \\
2008\end{array}$ & $\begin{array}{l}\text { RCAi in } \\
2018\end{array}$ & Product (3-digit SITC) & $\begin{array}{l}\text { RCAi } \\
2008\end{array}$ & $\begin{array}{l}\text { RCAi in } \\
2018\end{array}$ \\
\hline 272 Crude fertilizers & 0.9 & 4.9 & 971 Gold & 1.1 & 0 \\
\hline 344 Petroleum gases & 0.8 & 3.4 & 325 Coke of coal & 1.1 & 0.1 \\
\hline 343 Natural gas & 0.8 & 2.6 & 523 Metallic salts & 1.3 & 0.5 \\
\hline $\begin{array}{l}\text { 047 Other cereal meals and } \\
\text { flour }\end{array}$ & 0.3 & 1.6 & $\begin{array}{l}335 \text { Residual petroleum } \\
\text { product }\end{array}$ & 2.6 & 0.6 \\
\hline 684 Aluminium & 0.5. & 1.5 & 268 Wool & 2.8 & 0.4 \\
\hline 351 Electric current & 0.2 & 1.3 & 611 Leather & 4.5 & 0.2 \\
\hline 524 Other inorg. chemicals & 0.95 & 1.2 & & & \\
\hline 288 Waste and scrap & 0.3 & 1.2 & & & \\
\hline 062 Sugar confectionery & 0.1 & 1.1 & & & \\
\hline 091 Margarine & 0.3 & 1.1 & & & \\
\hline 122 Tobacco, manufactured & 0.3 & 1.0 & & & \\
\hline
\end{tabular}

Source: compiled by the author based on UNCTAD data.

Finally, we analyse the product groups in which Kazakhstan has managed to gain comparative advantage and the ones where the economy has lost it during the last decade. Table 2 indicates that over the period 2008-2018 diversification in the country increased as the products where competitiveness was achieved outnumbers by 5 products the ones where it was lost. Although this is an encouraging sign, the largest increase in products with positive RCA came from the primary commodities group. However, there are two product groups (electric current and inorganic chemicals) among the ones with gained comparative advantage which could be classified as technology-intensive and contributed not just to diversification but also the sophistication of the Kazakh export basket.

\section{Conclusion}

The results from the study show that reaching export diversification turns out to be a difficult long-term process. According to the most indicators applied Kazakhstan has achieved very little progress in diversifying its exports into non-extractive sectors during the review period even though it has been pursuing active industrial policies for 2 decades. This suggests that Kazakhstan should ensure better implementation, coordination, monitoring and evaluation of its diversification initiatives. That requires maintaining good governance and institutions and development of human capital including in the public administration. Furthermore, the success of such strategies rests on the efficient engagement of all stakeholders (businesses, NGOs, academia, the regions). 


\section{References}

1. British Petroleum, Statistical review of world energy (2019). URL: https://www.bp.com/en/global/corporate/energyeconomics/statistical-review-of-world-energy.html. Accessed: 05.09.2019.

2. K. Anderson, G. Capannelli, E. Ginting, K. Taniguchi (Eds.), Kazakhstan: Accelerating economic diversification (ADB, Mandaluyong City, Philippines, 2018). URL: https://www.adb.org/publications/kazakhstan-economicdiversification. Accessed: 05.09.2019.

3. European Bank for Reconstruction and Development, The fiscal implications for Kazakhstan of worldwide transition to a greener global economy (2018). URL: https:/www.ebrd.com/news/publications/special-reports/thefiscal-implications-for-kazakhstan-of-worldwide-transition-to-a-greener-global-economy.html. Accessed: 05.09.2019.

4. The Organisation for Economic Co-operation and Development (OECD), Enhancing competitiveness in Central Asia (2018). URL: https:/www.oecd.org/about/sge/enhancing-competitiveness-in-central-asia-9789264288133en.htm. Accessed: 05.09.2019.

5. V. Bayramov, L. Orujova, Volatility, diversification and oil shock in resource-rich Turkic countries: Avenues for recovery. Bilig, 83, 303-329 (2017).

6. P. Howie, Policy transfer and diversification in resource-dependent economies: Lessons for Kazakhstan from Alberta. Politics \& Policy, 46(1), 110-140 (2018).

7. UNCTAD, URL: https://unctadstat.unctad.org/wds/ReportFolders/reportFolders.aspx. Accessed: 05.09.2019.

8. Sovereign wealth fund «Samruk-Kazyna» JSC website. URL: https://sk.kz/about-fund/?lang=en. Accessed: 05.09.2019.

9. National Program of forced industrial and innovative development of the Republic of Kazakhstan 2010-2014, "Kazakhstanskaya pravda" March 31, 2010, \# 74 (26135).

10. M.M. Idrisov, Program of industrial and innovative development of the Republic of Kazakhstan for 2015-2019. Economy, Entrepreneurship and Law, 5(4), 253-272 (2015). DOI: 10.18334/epp.5.4.2111.

11. International Trade Centre, International trade statistics 2001-2019 (2019). URL: http://www.intracen.org/itc/market-info-tools/trade-statistics/. Accessed: 05.09.2019. 